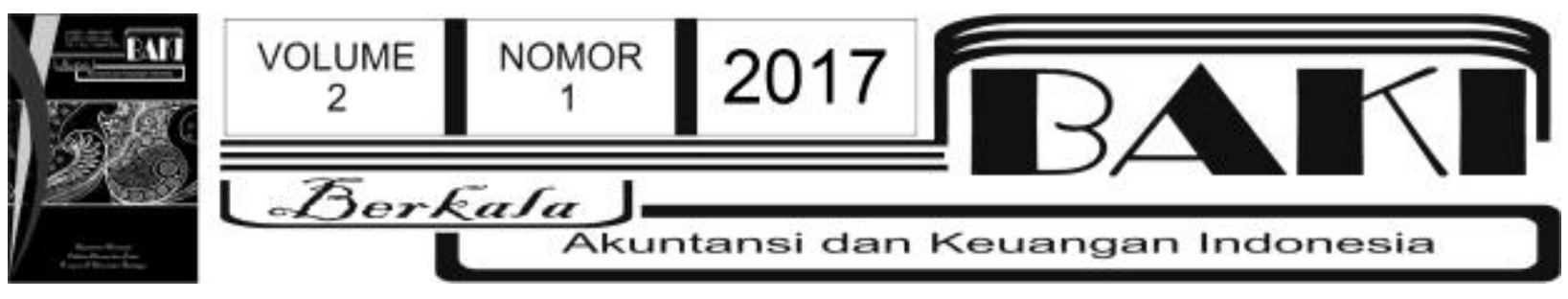

\title{
Apakah Kecakapan Managerial Mampu Memitigasi Manipulasi Aktivitas Riil? (Studi Empiris Pada Perusahaan Manufaktur di BEI Periode 2010-2015)
}

\author{
Ronald Tehupiring ${ }^{1}$ \\ ${ }^{1}$ Universitas Gadjah Mada \\ ${ }^{1}$ ronaldtehupuring@gmail.com
}

INFO ARTIKEL

Histori Artikel:

Tanggal Masuk 28 Februari 2017

Tanggal Diterima 16 Maret 2017

Tersedia Online 9 Mei 2017

Kata Kunci:

kecakapan managerial;

manipulasi aktivitas riil;

manajemen laba;

manipulasi laba

\begin{abstract}
A B STRAK
Tujuan perusahaan untuk mencapai target laba yang diinginkan bukan hanya dapat dilakukan melalui manipulasi laba. Akan tetapi, dapat juga dipengaruhi oleh faktor kecakapan managerial. Manager yang cakap akan mampu mendesain proses bisnis dengan baik dengan cara meminimalkan input untuk mencapai output yang optimal. Tujuan penelitian ini adalah untuk menguji apakah kecakapan managerial mampu memitigasi manipulasi aktivitas riil pada perusahaan manufaktur yang terdaftar di BEI periode 2010-2015 yang diperoleh melalui purposive sampling. Hasil penelitian menunjukkan bahwa kecakapan managerial mampu memitigasi manipulasi aktivitas riil yang diperoleh melalui pengujian secara statistik dengan menggunakan regresi linear berganda.
\end{abstract}

\section{Pendahuluan}

Laporan keuangan merupakan salah satu sumber informasi yang digunakan oleh pemangku kepentingan dalam menilai kinerja perusahaan. FASB (1978) menjelaskan bahwa tujuan pelaporan keuangan adalah untuk menyajikan informasi yang berguna bagi pemangku kepentingan dalam pengambilan keputusan bisnis. Informasi mengenai kinerja managemen perusahaan tercermin melalui informasi laba yang terkandung dalam laporan laba rugi perusahaan. Oleh karena itu, proses penyusunan laporan keuangan dapat dipengaruhi oleh faktor-faktor tertentu yang dapat menentukan kualitas laporan keuangan.

Dechow dan Dichev (2002) menyatakan bahwa laba yang berkualitas tinggi harus memiliki tiga karakteristik penting, yaitu (1) mampu menunjukkan kinerja operasional perusahaan saat ini secara akurat, (2) mampu memberikan informasi terkait indikator yang baik 
dalam menilai kinerja perusahaan di masa yang akan datang, dan (3) dapat dijadikan ukuran yang tepat dalam menilai kinerja perusahaan. Apabila kualitas laba mampu merepresentasikan ketiga karakteristik di atas, maka akan mengurangi adanya asimetri informasi antara managemen perusahaan dan pemegang saham.

Informasi laba sebagai tolok ukur penilaian kinerja perusahaan menyebabkan manager seringkali menggunakan berbagai cara untuk melakukan manipulasi laba agar kinerja perusahaan akan terlihat baik oleh pemangku kepentingan. Barth dkk., 1999; Barto dkk., 2002; Kasznik dan McNichols; 2002; Skinner dan Sloan, 2002; Brown dan Caylor, 2005; serta Rees dan Sivaramakrishnan (2007) menjelaskan bahwa pasar akan memberikan reward kepada perusahaan yang memenuhi atau mengalahkan benchmark laba. Sebaliknya, pasar akan memberikan punishment kepada perusahaan yang penghasilannya di bawah benchmark laba (Bernard., 1993; Skinner dan Sloan, 2002; Payne dan Thomas, 2010). Dengan adanya reward dan punishment menyebabkan manager yang memiliki tugas utama sebagai pengelola perusahaan akan berusaha untuk menyajikan laba yang optimal.

Manipulasi laba yang dilakukan oleh managemen perusahaan akan berdampak pada informasi laba yang dilaporkan kepada pemangku kepentingan. Fenomena mengenai manipulasi laba merupakan fenomena umum yang sering terjadi pada perusahan-perusahaan yang dilakukan baik secara legal maupun tidak legal. Praktik manipulasi laba yang dilakukan secara legal terjadi ketika manager berusaha untuk mempengaruhi angka laba yang tidak bertentangan dengan aturan pelaporan keuangan dalam PABU (Standar Akuntansi), yaitu dengan cara memanfaatkan peluang dari standar yang ada untuk membuat estimasi akuntansi, melakukan perubahan metode akuntansi, dan menggeser periode pendapatan atau biaya. Sebaliknya, praktik manipulasi laba yang dilakukan secara ilegal terjadi ketika manager melaporkan transaksi secara fiktif dengan cara menambah atau mengurangi nilai transaksi atau bahkan kemungkinan untuk tidak melaporkan sejumlah transaksi, sehingga akan mempengaruhi angka laba tertentu yang dikehendaki oleh manager.

Fenomena manipulasi laba secara legal maupun ilegal mengakibatkan pemangku kepentingan kurang percaya terhadap kredibilitas laporan keuangan yang dipublikasikan oleh perusahaan. Misalkan, berbagai kasus yang terjadi di Amerika Serikat seperti Enron Corporation, Worldcom, Tyco, dan Heal South (Ujiyantho dan Pamungkas, 2007). Sedangkan di Indonesia terjadi beberapa kasus seperti PT. Kimia Farma Tbk, PT. Indofarma Tbk, PT. Lippo Tbk, PT. Katarina Utama Tbk, PT.Bumi Resources Tbk, dan PT.Ades Alfindo Tbk (Vajriyanti dkk., 2015). Kasus-kasus ini menyebabkan laporan keuangan menjadi tidak berkualitas karena adanya bias pelaporan keuangan yang dapat mengganggu pemangku kepentingan dalam mempercayai angka laba hasil rekayasa managemen perusahaan sebagai angka laba yang sebenarnya. 
Graham dkk. (2005) dan Roychowdhury (2006) menjelaskan bahwa manager lebih menyukai aktivitas manipulasi aktivitas riil bila dibandingkan dengan manipulasi laba akrual. Hal ini disebabkan manipulasi aktivitas riil cenderung tidak dapat dibedakan dari keputusan bisnis optimal dan lebih sulit dideteksi oleh regulator dan auditor, meskipun biaya-biaya yang digunakan untuk menunjang aktivitas bisnis perusahaan secara ekonomis signifikan bagi perusahaan. Manipulasi aktivitas riil dapat dilakukan melalui arus kas operasi, biaya produksi, dan biaya diskresioner (Roychowdhury, 2006). Ketiga ukuran manipulasi aktivitas riil ini lebih berfokus pada income increasing untuk meningkatkan angka laba.

Manager memiliki motivasi untuk melakukan manipulasi laba dengan tujuan pelaporan keuangan tertentu telah terpenuhi dalam operasi normal perusahaan. Akan tetapi, hal ini akan membawa dampak negatif bagi pemegang saham karena terjadi bias keputusan investasi. Bushman dan Smith (2001) menjelaskan bahwa informasi akuntansi akan menjadi semakin berkualitas jika informasi tersebut dapat membantu pemegang saham dalam membedakan managemen perusahaan yang baik dan kurang baik, sehingga akan mempengaruhi keputusan pemegang saham dalam melakukan investasi secara tepat.

Tujuan perusahaan untuk mencapai target laba yang diinginkan bukan hanya dapat dilakukan melalui manipulasi laba. Akan tetapi, dapat juga dipengaruhi oleh faktor kecakapan managerial. Demerjian dkk. (2013) menjelaskan bahwa kecakapan managerial merupakan kemampuan manager dalam mengambil dan menerapkan keputusan-keputusan yang dapat mengantarkan perusahaan ke tingkat efisiensi yang tinggi. Efisiensi merupakan penggunaan sumber daya secara minimum untuk mencapai hasil yang optimum. Oleh karena itu, efisiensi menyiratkan adanya keputusan manajemen untuk mencapai tujuan perusahaan dengan menggunakan cara-cara yang optimal. Wagner (2008) menjelaskan bahwa manager memiliki tanggung jawab dan berperan penting atas pencapaian kinerja perusahaan.

Penelitian-penelitian pengaruh kecakapan managerial yang mempengaruhi hasil laporan keuangan perusahaan telah banyak diteliti. Akan tetapi, hasil-hasil penelitian sebelumnya menunjukkan kesimpulan yang tidak konsisten. Demerjian dkk. (2012) menunjukkan bahwa kecakapan managerial berpengaruh negatif terhadap total manipulasi laba (manipulasi laba akrual dan riil) dan manipulasi laba riil. Selain itu, Demerjian dkk. (2013) menunjukkan bahwa kecakapan managerial berpengaruh positif terhadap kualitas laba, sehingga manager yang cakap akan lebih menghindari adanya manipulasi laba. Aier dkk. (2005) menunjukkan bahwa CFO yang lebih memiliki keahlian akuntansi dapat mengurangi adanya penyajian kembali laporan keuangan. Akan tetapi, hasil penelitian Isnugrahadi dan Kusuma (2009) menunjukkan bahwa kecakapan managerial berpengaruh positif terhadap manipulasi laba akrual. Selain itu, penelitian yang dilakukan oleh Francis dkk. (2008) menunjukkan bahwa CEO yang bereputasi 
akan berhubungan dengan kualitas laba yang semakin rendah, sehingga CEO yang lebih bereputasi berhubungan positif dengan manipulasi laba.

Ketidakkonsistenan antara penelitian yang dilakukan oleh Aier dkk. (2005) dan Demerjian dkk. (2013) dengan Francis dkk. (2008), Isnugrahadi dan Kusuma (2009), dan Demerjian dkk. (2012) menyebabkan peneliti berpikir untuk menguji kembali penelitian-penelitian tersebut jika dilihat dari sisi manipulasi aktivitas riil. Hal ini disebabkan karena penelitian-penelitian sebelumnya lebih menekankan pengaruh kecakapan managerial terhadap manipulasi laba akrual.

Penelitian ini penting dilakukan untuk menyediakan bukti bahwa informasi laba yang terkandung dalam laporan keuangan tidak bias karena tidak mengandung adanya manipulasi aktivitas riil yang dilakukan oleh managemen perusahaan. Pada dasarnya peneliti percaya bahwa managemen perusahaan akan menggunakan kecakapannya untuk meningkatkan laba, sehingga laba perusahaan memiliki kualitas tinggi. Oleh karena itu, manager yang cakap akan menghindari adanya manipulasi laba (Demerjian dkk., 2013). Dengan demikian, pengambilan keputusan yang dilakukan oleh pemangku kepentingan akan tepat sesuai dengan informasi laba yang dilaporkan oleh managemen perusahaan.

Penelitian ini mengikuti penelitian-penelitian yang dilakukan oleh Aier dkk. (2005); Francis dkk. (2008); Isnugrahadi dan Kusuma (2009), Demerjian dkk. (2012); dan Demerjian dkk. (2013) yang mengukur kecakapan managerial dan informasi laba yang terkandung dalam laporan keuangan. Asumsi yang digunakan dalam penelitian ini adalah asumsi linearitas yang didasarkan atas keyakinan bahwa manager yang memiliki kecakapan akan berusaha untuk mencapai laba yang berkualitas yang terhindar dari adanya manipulasi laba. Peneliti percaya bahwa laba yang berkualitas akan mempengaruhi pengambilan keputusan yang tepat yang dapat membawa perusahaan untuk terus bertumbuh karena informasi laba mencerminkan informasi yang sesungguhnya.

Hasil penelitian yang diharapkan oleh peneliti adalah kecakapan managerial mampu memitigasi tindakan manager melakukan manipulasi aktivitas riil. Artinya, manager akan menggunakan kecakapannya untuk menggunakan sumber daya secara efektif dalam mencapai laba yang optimal daripada manager melakukan manipulasi laba yang berdampak pada kinerja jangka panjang dan kehilangan kepercayaan publik. Berdasarkan latar belakang di atas, maka rumusan masalah dalam penelitian ini adalah apakah kecakapan managerial mampu memitigasi manipulasi aktivitas riil? Tujuan penelitian ini adalah untuk menguji dan menganalisis kecakapan managerial dalam memitigasi manipulasi aktivitas rill. 


\section{Tinjauan Pustaka}

\subsection{Teori Keagenan}

Teori agensi menjelaskan bahwa adanya kepentingan yang berbeda antara pemilik dan managemen (Jensen dan Meckling, 1976). Pemilik diasumsikan hanya tertarik kepada hasil investasi perusahaan. Sedangkan manager diasumsikan ingin memenuhi kebutuhannya melalui kompensasi dan bonus yang diterimanya. Hal ini menyebabkan munculnya perilaku oportunistik manager untuk bertindak sesuai dengan kepentingannya. Akan tetapi, jika dilihat dari perspektif kontrak efisien, managemen perusahaan akan berusaha untuk menyajikan laporan laba yang mencerminkan laba yang sesungguhnya sehingga informasi laba semakin ditingkatkan dalam mengkomunikasikan informasi privat. Penelitian ini mengkaji agensi teori dari perspektif kontrak efisien untuk menjelaskan perilaku manager dalam memitigasi manipulasi aktivitas riil. Hal ini dapat dijelaskan bahwa manager yang cakap akan mampu mendesain proses bisnis perusahaan yang efisien dan membuat keputusan-keputusan yang memberikan nilai tambah bagi perusahaan yang akan mengantarkan perusahaan mencapai target laba optimal, jika dibandingkan dengan pilihan manager untuk melakukan manipulasi aktivitas riil yang dapat memberikan dampak negatif bagi perusahaan berupa turunnya kepercayaan publik dan buruknya kinerja jangka panjang perusahaan.

\subsection{Penelitian Terdahulu dan Pengembangan Hipotesis}

Penelitian sebelumnya mengenai faktor-faktor yang mempengaruhi hasil laporan keuangan telah dilakukan oleh Aier dkk. (2005), Francis dkk. (2008), Isnugrahadi dan Kusuma (2009), Demerjian dkk. (2012), (2013). Hasil penelitian Aier dkk. (2005) menunjukkan bahwa CFO yang memiliki keahlian akuntansi yang lebih baik dapat mengurangi adanya penyajian kembali laporan keuangan. Persamaan penelitian ini dengan penelitian Aier dkk. (2005) adalah sama-sama menguji pengaruh kecakapan managerial terhadap kualitas pelaporan keuangan. Perbedaannya adalah penelitian ini mengkaji kecakapan managerial dari sisi tingkat efisiensi relatif sebuah perusahaan dalam mengelola input untuk meningkatkan output dalam memperoleh skor DEA. Selain itu, kualitas pelaporan keuangan dalam penelitian ini tercermin dari penggunaan manipulasi aktivitas riil.

Hasil penelitian Francis dkk. (2008) menunjukkan bahwa CEO yang bereputasi berhubungan dengan kualitas laba yang rendah. Persamaan penelitian ini dengan penelitian Francis dkk. (2008) adalah sama-sama menguji pengaruh kecakapan managerial terhadap kualitas pelaporan keuangan. Perbedaannya adalah penelitian ini mengkaji kecakapan 
managerial dari sisi tingkat efisiensi relatif sebuah perusahaan dalam mengelola input untuk meningkatkan output dalam memperoleh skor DEA. Selain itu, kualitas pelaporan keuangan dalam penelitian ini tercermin dari penggunaan manipulasi aktivitas riil.

Hasil penelitian Isnugrahadi dan Kusuma (2009) menunjukkan bahwa kecakapan managerial berpengaruh positif terhadap manajemen laba akrual. Persamaan penelitian ini dengan penelitian Isnugrahadi dan Kusuma (2009) adalah sama-sama menguji pengaruh kecakapan managerial terhadap kualitas pelaporan keuangan. Perbedaannya adalah penelitian ini mengkaji kecakapan managerial dari sisi tingkat efisiensi relatif sebuah perusahaan dalam mengelola input untuk meningkatkan output dalam memperoleh skor DEA. Skor DEA yang digunakan dalam perhitungan ini merupakan hasil perhitungan rumus DEA dengan modifikasi penelitian Isnugrahadi dan Kusuma (2009) dengan Demerjian dkk. (2012). Selain itu, kualitas pelaporan keuangan dalam penelitian ini tercermin dari penggunaan manipulasi aktivitas riil. Sedangkan, Isnugrahadi dan Kusuma (2009) mengkaji kualitas pelaporan keuangan dari sisi manajemen laba akrual.

Hasil penelitian Demerjian dkk. (2012) menunjukkan bahwa kecakapan managerial berpengaruh negatif teradap total managemen laba (akural dan riil) dan manajemen laba riil. Persamaan penelitian ini dengan penelitian Demerjian dkk. (2012) adalah sama-sama menguji pengaruh kecakapan managerial terhadap kualitas pelaporan keuangan. Perbedaannya adalah penelitian ini mengkaji kecakapan managerial dari sisi tingkat efisiensi relatif sebuah perusahaan dalam mengelola input untuk meningkatkan output dalam memperoleh skor DEA. Skor DEA yang digunakan dalam perhitungan ini merupakan hasil perhitungan rumus DEA dengan modifikasi penelitian Isnugrahadi dan Kusuma (2009) dengan Demerjian dkk. (2012). Selain itu, kualitas pelaporan keuangan dalam penelitian ini tercermin dari penggunaan manipulasi aktivitas riil dengan mengikuti perhitungan manipulasi aktivitas riil berdasarkan Roychowdhury (2006) dengan pengukuran komprehensif mengikuti Wu dkk. (2015).

Hasil penelitian Demerjian dkk. (2013) menunjukkan bahwa kecakapan managerial berpengaruh positif terhadap kualitas laba. Persamaan penelitian ini dengan penelitian Demerjian dkk. (2012) adalah sama-sama menguji pengaruh kecakapan managerial terhadap kualitas pelaporan keuangan. Perbedaannya adalah penelitian ini mengkaji kecakapan managerial dari sisi tingkat efisiensi relatif sebuah perusahaan dalam mengelola input untuk meningkatkan output dalam memperoleh skor DEA. Skor DEA yang digunakan dalam perhitungan ini merupakan hasil perhitungan rumus DEA dengan modifikasi penelitian Isnugrahadi dan Kusuma (2009) dengan Demerjian dkk. (2012). Selain itu, kualitas pelaporan keuangan dalam penelitian ini tercermin dari penggunaan manipulasi aktivitas riil dengan mengikuti perhitungan manipulasi aktivitas riil berdasarkan Roychowdhury (2006) dengan pengukuran komprehensif mengikuti Wu dkk. (2015). 


\subsubsection{Pengaruh Kecakapan Managerial terhadap Manipulasi Aktivitas Riil}

Teori agensi menjelaskan adanya konflik kepentingan antara managemen dan pemilik (Jensen dan Meckling, 1976). Konflik kepentingan tersebut dimotivasi oleh keinginan manager untuk memenuhi kepentingannya melalui kompensasi dan bonus, sedangkan pemilik juga ingin memenuhi kepentingganya melalui return yang akan diterimanya. Hal ini disebabkan karena adanya perilaku oportunis manager. Akan tetapi, jika dilihat dari perspektif kontrak efisien, manager perusahaan akan berusaha untuk menyajikan laporan laba yang mencerminkan laba yang sesungguhnya sehingga informasi laba semakin ditingkatkan dalam mengkomunikasikan informasi privat. Penelitian ini mengkaji agensi teori dari perspektif kontrak efisien untuk menjelaskan perilaku manager dalam memitigasi manipulasi aktivitas riil.

Manager yang cakap akan mampu mengambil keputusan-keputusan ekonomi yang tepat untuk mencapai tingkat efisiensi yang tinggi dalam mengelola sumber daya perusahaan karena didukung dengan pengalaman, tingkat intelegensia, dan tingkat pendidikan yang tinggi, sehingga manajer mampu meraih laba yang optimal. Manager yang cakap akan berusaha untuk terus meningkatkan kualitas kinerjanya dengan menggunakan sumber daya secara tepat agar dapat memberikan nilai tambah bagi perusahaan daripada manager harus melakukan managemen laba yang memiliki resiko gagal dalam mempertahankan kepercayaan pemegang saham. Manager yang memiliki pengetahuan bisnis yang baik, kemampuan judgment dan estimasi yang akurat, serta ahli dalam bidang tanggung jawabnya akan mengambil keputusan bisnis yang berdampak pada aktivitas perusahaan yang efisien. Dampak dari adanya pengetahuan bisnis yang baik, kemampuan pengambilan keputusan yang efektif dan efisien, serta keahlian yang dimiliki oleh manager yaitu akan memberikan nilai tambah bagi perusahaan untuk mencapai laba yang optimal.

Manipulasi aktivitas riil merupakan pengelolaan nilai laba yang dilakukan oleh managemen perusahaan melalui aktivitas riil selama periode akuntansi. Ketika managemen perusahaan melakukan managemen laba melalui aktivitas riil, maka kinerja jangka pendek perusahaan akan terlihat baik. Akan tetapi, managemen perusahaan akan mengorbankan kinerja jangka panjang dan aliran kas perusahaan. Hal ini sesuai dengan yang dikemukakan oleh Gunny (2005) dan Roychowdhury (2006) bahwa tindakan yang dilakukan oleh managemen perusahaan untuk meningkatkan laba jangka pendek akan memiliki dampak negatif terhadap kinerja jangka panjang perusahaan. Laba yang turun pada periode berikutnya akan mempengaruhi turunnya harga saham perusahaan sehingga kinerja perusahaan akan turun. 
Hasil penelitian yang dilakukan oleh Demerjian dkk. (2012) menunjukkan bahwa kecakapan managerial berpengaruh negatif terhadap total managemen laba dan managemen laba riil. Artinya bahwa semakin tinggi kecakapan managerial, maka semakin rendah managemen laba riil. Chen dan Wakabayashi (1997) menunjukkan bahwa manager menggunakan kecakapannya untuk meningkatkan kinerja perusahaan melalui strategi thinking skill, proper use of personel, quality control, profit consciousenes, innovativeness, fair treatment, technical expertise, decision making skill, motivating skil, dan system development. Studi ini selanjutnya mengajukan hipotesis sebagai berikut.

$\mathrm{H}_{1}$ : Kecakapan Managerial mampu Memitigasi Manipulasi Aktivitas Riil.

Gambar 1. Berikut ini merupakan model penelitian ini.

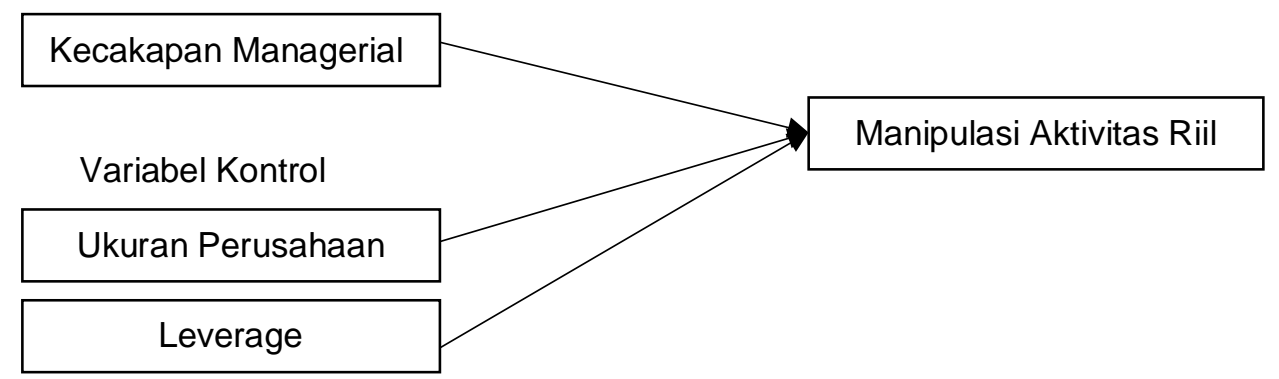

\section{Metodologi Penelitian}

\subsection{Definisi Operasional dan Pengukuran Variabel}

1). Manipulasi Aktivitas Riil melalui Arus Kas Aktivitas Operasi

Pendeteksian managemen laba riil menggunakan arus kas aktivitas operasi abnormal (ABN_CFO). Setiap observasi arus kas aktivitas operasi abnormal diperoleh dari selisih arus kas aktivitas operasi aktual yang diskalakan dengan total aset tahun sebelum pengujian dengan arus kas aktivitas operasi normal yang dihitung dengan menggunakan koefisien estimasi yang diperoleh dari persamaan regresi sebagai berikut:

$$
\text { CFOt/At-1 }=\alpha 0+\alpha 1(1 / A t-1)+\beta 1(\text { St } / A t-1)+\beta 2(\Delta S t / A t-1)+\varepsilon
$$

Keterangan:

CFOt/At-1 = Arus kas kegiatan operasi pada tahun $t$ yang diskala dengan total aset pada tahun $\mathrm{t}-1$.

$\alpha 1(1 / A t-1)=$ Intersep yang diskala dengan total aset pada tahun $\mathrm{t}-1$ dengan tujuan supaya arus kas aktivitas operasi tidak bernilai 0 ketika penjualan dan lag penjualan bernilai 0 .

$\mathrm{b} 1$ (St/At-1) = Penjualan pada tahun $\mathrm{t}$ yang diskala dengan total aset pada tahun $\mathrm{t}-1$.

b2 $(\Delta \mathrm{St} / \mathrm{At}-1)=$ Penjualan pada tahun $\mathrm{t}$ dikurangi penjualan pada tahun $\mathrm{t}-1$ yang diskala dengan total aset pada tahun $\mathrm{t}-1$. 


\section{Manipulasi Aktivitas Riil melalui Biaya Produksi}

Pendeteksian managemen laba riil menggunakan biaya produksi abnormal (ABN_PROD). Biaya produksi yang digunakan dalam penelitian ini diperoleh dengan cara menjumlahkan harga pokok penjualan dengan perubahan persediaan. Setiap observasi biaya produksi abnormal diperoleh dari selisih biaya produksi aktual yang diskalakan dengan total aset satu tahun sebelum pengujian dengan biaya produksi normal yang dihitung dengan menggunakan koefisien estimasi yang diperoleh dari persamaan regresi sebagai berikut.

$$
\text { PRODt/At-1 }=\alpha 0+\alpha 1(1 / A t-1)+\beta 1(\text { St } / A t-1)+\beta 2(\Delta \text { St/At-1 })+\beta 3(\Delta \text { St-1/At-1 })+\varepsilon t
$$

Keterangan:

PRODt/At-1 = Biaya produksi pada tahun t yang diskala dengan total aset pada tahun $\mathrm{t}-1$, dimana PRODt $=$ COGSt $+\Delta \mathrm{INV}$.

(1/At-1) = Intersep yang diskala dengan total aset pada tahun $\mathrm{t}-1$ dengan tujuan supaya nilai biaya produksi tidak memiliki nilai 0 ketika penjualan dan lag penjualan bernilai 0 .

$($ St/At-1) $\quad=$ Penjualan pada tahun $t$ yang diskala dengan total aset pada tahun $\mathrm{t}-1$.

$(\Delta \mathrm{St} / \mathrm{At}-1) \quad=$ Penjualan pada tahun $\mathrm{t}$ dikurangi penjualan pada tahun $\mathrm{t}-1$ yang diskala dengan total aset pada tahun $\mathrm{t}-1$.

$($ St-1/At-1) = Penjualan pada tahun $\mathrm{t}-1$ yang diskala dengan total aset pada tahun $\mathrm{t}-1$.

\section{Manipulasi Aktivitas Riil melalui Biaya Diskresioner}

Pendeteksian managemen laba riil menggunakan biaya diskresioner abnormal (ABN_DISEXP). Biaya diskresioner yang digunakan dalam penelitian ini diperoleh dengan cara menjumlahkan biaya iklan, biaya riset dan pengembangan, biaya penjualan dan administrasi dan umum. Setiap observasi biaya diskresioner abnormal diperoleh dari selisih biaya diskresioner aktual yang diskalakan dengan total aset satu tahun sebelum pengujian dengan biaya diskresioner normal yang dihitung dengan menggunakan koefisien estimasi yang diperoleh dari persamaan regresi sebagai berikut.

$$
\text { DISEXPt/At-1 }=\alpha 0+\alpha 1(1 / \text { At-1 })+\beta 1(\text { St-1/At-1) }+\varepsilon t
$$

Keterangan:

DISEXPt/At-1 = Biaya diskresioner pada tahun $t$ yang diskala dengan total aset tahun $\mathrm{t}-1$.

$\mathrm{a}_{1}(1 / \mathrm{At}-1) \quad=$ Intersep yang diskala dengan total aset pada tahun $\mathrm{t}-1$ dengan tujuan supaya biaya diskresioner tidak memiliki nilai 0 ketika penjualan dan lag penjualan bernilai 0 .

$\mathrm{b}_{1}($ St-1/At-1) $=$ Penjualan pada tahun $\mathrm{t}-1$ yang diskala dengan total aset pada tahun $\mathrm{t}-1$.

$\alpha \quad=$ Konstanta

$\varepsilon \quad=$ Error term pada tahun $\mathrm{t}$.

Pengukuran manipulasi aktivitas riil secara komprehensif diperoleh dengan cara mengakumulasikan ketiga komponen di atas, yaitu abnormal production cost (ABN_PROD), abnormal cash flow operation (ABN_CFO), dan abnormal discretionary expenses 
(ABN_DISEXP). Ketiga komponen di atas merupakan hasil kombinasi yang digunakan oleh Wu dkk. (2015) yang didasarkan pada penelitian Zang (2012) dan Cohen dkk. (2008).

Sesuai dengan penelitian yang dilakukan oleh Zang (2012) dan Cohen dkk. (2008), untuk memperoleh proksi komprehensif dari manipulasi aktivitas riil, maka terlebih dahulu menyamakan arah abnormal cash flow operation dan abnormal disexpense dengan cara dikalikan dengan -1 , setelah itu dijumlahkan ketiga proksi di atas untuk memperoleh proksi keseluruhan dari manipulasi aktivitas riil. Dengan demikian, rumus di atas dapat ditulis sebagai berikut.

$$
\text { MALR }=\text { ACFO }(-1)+\text { ADISEXP }(-1)+\text { APROD }
$$

Atau dengan kata lain, rumus di atas dapat ditulis sesuai hasil kombinasi yang digunakan oleh Wu dkk. (2015) yang didasarkan pada penelitian Zang (2012) dan Cohen dkk. (2008), yaitu sebagai berikut.

$$
M A L R=A P R O D-A C F O-A D I S E X P
$$

\subsubsection{Kecakapan Managerial}

Kecakapan managerial merupakan kemampuan manager dalam mengambil dan menerapkan keputusan-keputusan bisnis perusahaan yang dapat mengantar perusahaan ke tingkat efisiensi (Demerjian dkk., 2012). Pengukuran kecakapan managerial dalam penelitian ini dilakukan dengan data envelopment analysis (DEA) seperti yang dilakukan oleh Demerjian dkk. (2013). DEA merupakan suatu program optimasi yang digunakan untuk mengevaluasi efisiensi realtif suatu unit dalam membuat keputusan (decision making unit) dengan cara membandingkan output atau multi output dengan input atau multi input. mengadopsi dari isnugrahadi dan Kusuma (2009). Kecakapan managerial diukur menggunakan Data Envelopment Analysis (DEA). DEA adalah sebuah program optimasi yang digunakan untuk mengevaluasi efisiensi relatif suatu Unit Kegiatan Ekonomi (UKE) berupa perbandingan antara output atau multi output dengan input atau multi input (Isnugrahadi dan Kusuma, 2009).

Kecakapan Managerial dalam penelitian ini didefinisikan sebagai tingkat keefisienan relatif sebuah perusahaan dalam mengelola input (faktor sumber daya dan operasional) untuk meningkatkan output (penjualan). Skor yang diperoleh digunakan untuk menilai efisiensi manager. Output yang digunakan hanya satu yaitu penjualan (sales). Penjualan digunakan sebagai output karena penjualan merupakan representasi dari nilai nominal produk perusahaan (Demerjian, 2013). Input yang digunakan dalam penelitian ini adalah sebagai berikut:

a. Cost of Good Sold (COGS), merupakan biaya yang memberikan kontribusi langsung pada penjualan (Demerjian, 2013). 
b. Selling, General, and Administrative Cost (SGA), secara tidak langsung mempengaruhi penjualan karena meliputi kompensasi kepada managemen, biaya penyelenggaraan kantor secara umum, dan biaya lain untuk mendukung penjualan. Penjualan tidak mungkin berjalan efektif tanpa unsur SGA ini (Demerjian, 2013).

c. Property, Plant, and Equipment (PPE), merupakan bentuk keputusan investasi yang diambil oleh manajemen. Perusahaan akan menjadi lebih efisien bila dapat menghasilkan penjualan dalam jumlah yang sama dengan perusahaan lain tetapi dengan jumlah investasi yang lebih kecil (Demerjian, 2013).

d. Jumlah Tenaga Kerja, merupakan faktor sumber daya lain yang berperan menghasilkan penjualan. Semakin kecil jumlah tenaga kerja untuk menghasilkan penjualan yang sama maka semakin efisien sebuah perusahaan (Isnugrahadi dan Kusuma, 2009).

Berdasarkan pengukuran input dan output untuk mengukur kecakapan managerial, maka nilai efisiensi tidak akan melebihi 1 (100\%) dan nilai input output yang harus dianalisis harus positif.

\subsubsection{Total Asset}

Keakuratan sistem pelaporan keuangan mungkin akan berbeda pada perusahaan yang memiliki ukuran perusahaan yang berbeda. Lebih besar ukuran perusahaan maka akan lebih besar pula keakuratan sistem pelaporan keuangannya. Dalam penelitian ini, ukuran perusahaan diukur dengan menggunakan nilai logaritma natural total aset.

\subsubsection{Leverage}

Leverage adalah kemampuan mengungkit perusahaan untuk mencari laba. Variabel leverage dihitung dengan membagi total utang dengan total aset.

\subsection{Populasi dan Sampel}

Populasi dalam penelitian ini adalah perusahaan manufaktur yang terdaftar di Bursa Efek Indonesia (BEl). Tabel 3.1 menunjukkan populasi dan sampel yang digunakan dalam penelitian ini yaitu perusahaan manufaktur yang terdaftar di Bursa Efek Indonesia (BEI). Periode penelitian adalah dari tahun 2008-2015. Peneliti menggunakan tahun 2008 dan 2009 untuk menghitung variabel manipulasi aktivitas riil sebagai tahun dasar.

Tabel 1. Proses Pemilihan Sampel Perusahaan

\begin{tabular}{|c|l|c|}
\hline No. & \multicolumn{1}{|c|}{ Kriteria Sampel } & $\begin{array}{c}\text { Jumlah } \\
\text { Sampel }\end{array}$ \\
\hline 1. & $\begin{array}{l}\text { Perusahaan manufaktur yang terdaftar di BEI 2008- } \\
2015\end{array}$ & 118 \\
\hline 2. & Data tidak lengkap & $(6)$ \\
\hline 3. & $\begin{array}{l}\text { Jumlah perusahaan dalam masing-masing sub } \\
\text { sektor industri yang kurang dari 5 (lima) }\end{array}$ & $(23)$ \\
\hline & Sampel penelitian & 89 \\
\hline
\end{tabular}




\begin{tabular}{|l|l|c|}
\hline & Sampel observasi penelitian $(89 \times 6)$ & 534 \\
\hline & Outliers (peluar) & $(127)$ \\
\hline & Total Sampel observasi akhir & 407 \\
\hline
\end{tabular}

Sumber: data sekunder diolah, 2017

\subsection{Teknik Analisis}

Hipotesis yang digunakan dalam penelitian ini akan diuji dengan regresi linear berganda. Akan tetapi, sebelum hipotesis diuji terlebih dahulu akan diuji asumsi klasik untuk memperoleh hasil yang BLUE (best linear unbiased estimation). Berdasarkan model penelitian di atas, maka persamaan ekonometrik dalam penelitian ini sebagai berikut.

$$
\operatorname{MAR}=\alpha+\beta 1 K C M+\beta 2 L T A+\beta 3 L E V+\varepsilon
$$

Keterangan:

MAR = Manipulasi Aktivitas Riil

$\mathrm{KCM}=$ Kecakapan Managerial

LTA = Logaritma Total Aset

LEV = Leverage

$\alpha \quad=$ Konstanta

$\beta 1-\beta 3=$ Koefisien regresi

\section{Analisis dan Pembahasan}

Tabel 2 menunjukkan statistik deskriptif yang terdiri dari jumlah observasi $(\mathrm{N})$, nilai minimum, maksimum, mean, dan standar deviasi

Tabel 2. Statistik Deskriptif

\begin{tabular}{|l|c|c|c|c|c|}
\hline \multicolumn{1}{|c|}{ Variabel } & $\mathbf{N}$ & Minimum & Maksimum & Mean & Std.Deviasi \\
\hline KCM & 407 & 0.53 & 1.00 & 0.963 & 0.066 \\
\hline MAR & 407 & -0.574 & 0.685 & 0.003 & 0.197 \\
\hline LTA & 407 & 12.35 & 34.53 & 0.141 & 0.126 \\
\hline LEV & 407 & 0.037 & 3 & 0.480 & 0.255 \\
\hline
\end{tabular}

Sumber: data sekunder diolah, 2017

Tabel 2 di atas menunjukkan bahwa kecakapan managerial memiliki nilai terendah 0.53 dan nilai tertinggi 1.00. Selain itu, nilai rata-rata 0.963 dan standar deviasi 0.066 . Hal ini menunjukkan bahwa rata-rata kecakapan managerial tergolong tinggi dalam perusahaan manufaktur selama periode 2010-2015. Dengan demikian, peneliti dapat menuimpulkan bahwa manager pada perusahaan manufaktur mampu melakukan efisiensi input untuk mencapai output yang optimal. 
Manipulasi aktivitas memiliki nilai terendah -0.574 dan nilai tertinggi 0.685 . Selain itu, nilai rata-rata 0.003 dan standar deviasi 0.197 . Hal ini menunjukkan bahwa rata-rata manipulasi aktivitas riill tergolong rendah dalam perusahaan manufaktur selama periode 2010-2015. Dengan demikian, peneliti dapat menyimpulkan bahwa manager pada perusahaan manufaktur melakukan manipulasi aktivitas riil masih tergolong rendah jika dikaitkan degan nilai tertinggi manipulasi aktivitas riil.

Total aset memiliki nilai terendah 12.35 dan nilai tertinggi 34.53. Selain itu, nilai rata-rata 0.141 dan standar deviasi 0.126 . Nilai total aset perusahaan manufaktur yang dijadikan sampel penelitian ini merupakan nilai total aset setelah dilogaritma naturalkan.

Leverage memiliki nilai terendah 0.037 dan nilai tertinggi 3. Selain itu, nilai rata-rata 0.480 dan standar deviasi 0.255 . Hal ini menunjukkan bahwa rata-rata leverage tergolong tinggi dalam perusahaan manufaktur selama periode 2010-2015. Dengan demikian, peneliti dapat menyimpulkan bahwa manager pada perusahaan manufaktur mampu membiayai utang dari total aset.

Data deskriptif skor DEA kecakapan managerial dapat dilihat pada tabel 3 berikut ini.

Tabel 3. Skor DEA Kecakapan Managerial

\begin{tabular}{|l|l|c|c|c|c|c|c|c|}
\hline \multirow{3}{*}{ No. } & \multirow{2}{*}{ Sub Sektor Industri } & \multicolumn{6}{|c|}{ Skor DEA } \\
\cline { 3 - 8 } & & Tertinggi & \multicolumn{4}{|c|}{ Terendah } \\
\cline { 3 - 8 } & & $\mathbf{2 0 1 0 - 2 0 1 5}$ & $\mathbf{2 0 1 0}$ & $\mathbf{2 0 1 1}$ & $\mathbf{2 0 1 2}$ & $\mathbf{2 0 1 3}$ & $\mathbf{2 0 1 4}$ & $\mathbf{2 0 1 5}$ \\
\hline 1. & Ceramics, Glas, dan Porcelain & 1 & 0.77 & 0.78 & 0.71 & 0.71 & 0.75 & 0.74 \\
\hline 2. & Metal dan Allied Product & 1 & 0.90 & 0.82 & 0.69 & 0.81 & 0.80 & 0.81 \\
\hline 3. & Chemical & 1 & 0.88 & 0.96 & 0.87 & 0.81 & 0.88 & 0.91 \\
\hline 4. & Plastics dan Packaging & 1 & 0.97 & 0.92 & 0.78 & 0.96 & 0.91 & 0.91 \\
\hline 5. & Pulp dan Paper & 1 & 0.70 & 0.66 & 0.69 & 0.75 & 0.87 & 0.92 \\
\hline 6. & Automotive dan Components & 1 & 0.86 & 0.92 & 0.87 & 0.87 & 0.85 & 0.94 \\
\hline 7. & Textile dan Garment & 1 & 0.92 & 0.78 & 0.86 & 0.84 & 0.63 & 0.80 \\
\hline 8. & Cable & 1 & 0.95 & 0.93 & 0.96 & 0.96 & 0.91 & 0.99 \\
\hline 9. & Food dan Baverage & 1 & 0.82 & 0.78 & 0.80 & 0.77 & 0.81 & 0.53 \\
\hline 10. & Pharmaceuticals & 1 & 0.87 & 0.68 & 0.70 & 0.71 & 0.73 & 0.77 \\
\hline
\end{tabular}

Sumber: data sekunder diolah, 2017

Tabel 3 di atas menunjukkan bahwa skor DEA untuk setiap sub sektor industri berfluktuasi dari tahun 2010-2015. Skor DEA kecakapan managerial untuk setiap sub sektor industri berfluktuasi dari tahun 2010-2015. Fluktuasi yang paling signifikan terjadi pada sub sektor industri food and beverage yaitu untuk tahun 2010 sebesar 0.82 , sedangkan untuk tahun 2015 sebesar 0.53, jika dibandingkan dengan fluktuasi yang terjadi pada sub sektor industri lainnya.

Data deskriptif rata-rata skor DEA kecakapan managerial dapat dilihat pada tabel 4 berikut ini.

Tabel 4. Rata-Rata Skor DEA Kecakapan Managerial

\begin{tabular}{|l|c|c|c|c|c|c|c|}
\hline \multirow{2}{*}{ No. } & \multirow{2}{*}{ Sub Sektor Industri } & \multicolumn{6}{|c|}{ Rata-Rata Skor DEA } \\
\cline { 3 - 7 } & 2010 & 2011 & 2012 & 2013 & 2014 & 2015 \\
\hline
\end{tabular}




\begin{tabular}{|c|l|c|c|c|c|c|c|}
\hline 1. & $\begin{array}{l}\text { Ceramics, Glas, dan } \\
\text { Porcelain }\end{array}$ & 0.94 & 0.92 & 0.93 & 0.95 & 0.93 & 0.88 \\
\hline 2. & $\begin{array}{l}\text { Metal dan Allied } \\
\text { Product }\end{array}$ & 0.98 & 0.96 & 0.93 & 0.96 & 0.96 & 0.94 \\
\hline 3. & Chemical & 0.98 & 0.99 & 0.97 & 0.96 & 0.97 & 0.99 \\
\hline 4. & Plastics dan Packaging & 0.99 & 0.98 & 0.96 & 0.99 & 0.98 & 0.97 \\
\hline 5. & Pulp dan Paper & 0.95 & 0.95 & 0.95 & 0.92 & 0.96 & 0.96 \\
\hline 6. & $\begin{array}{l}\text { Automotive dan } \\
\text { Components }\end{array}$ & 0.98 & 0.97 & 0.96 & 0.95 & 0.94 & 0.97 \\
\hline 7. & Textile dan Garment & 0.98 & 0.95 & 0.96 & 0.96 & 0.92 & 0.93 \\
\hline 8. & Cable & 0.99 & 0.98 & 0.99 & 0.99 & 0.97 & 0.99 \\
\hline 9. & Food dan Baverage & 0.95 & 0.92 & 0.95 & 0.91 & 0.92 & 0.83 \\
\hline 10. & Pharmaceuticals & 0.96 & 0.90 & 0.89 & 0.90 & 0.90 & 0.89 \\
\hline
\end{tabular}

Sumber: data sekunder diolah, 2017

Tabel 4 di atas menunjukkan bahwa rata-rata skor DEA untuk setiap sub sektor industri berfluktuasi dari tahun 2010-2015. Fluktuasi yang paling signifikan terjadi pada sub industri food and beverage yaitu untuk tahun 2010 sebesar 0.95, sedangkan untuk tahun 2015 sebesar 0.83 .

Data pengujian normalitas dapat dilihat pada tabel 5 berikut ini.

Tabel 5. Hasil Uji Normalitas

\begin{tabular}{|l|c|}
\hline & Uji Normalitas \\
\hline Kolmogorov-Smirnov Z & 1.209 \\
\hline Asymp. Sig. (2-tailed) & 0.108 \\
\hline
\end{tabular}

Sumber: data sekunder diolah, 2017

Tabel 5 di atas menunjukkan bahwa hasil pengujian normalitas dengan menggunakan kolmogorov smirnov memenuhi asumsi normalitas. Hal ini ditunjukkan dari nilai signifikansi hasil pengujian sebesar $0.108>0.05$. Dengan demikian, peneliti dapat menyimpulkan bahwa residual terdistrubusi normal.

Data pengujian multikolinearitas dapat dilihat pada tabel 6 berikut ini.

Tabel 6. Hasil Uji Multikolinearitas

\begin{tabular}{|l|c|c|}
\hline \multirow{2}{*}{ Variabel } & \multicolumn{2}{|c|}{ Collinearity Statistics } \\
\cline { 2 - 3 } & Tolerance & VIF \\
\hline KCM & 0.996 & 1.004 \\
\hline LTA & 0.937 & 1.068 \\
\hline LEV & 0.934 & 1.071 \\
\hline
\end{tabular}

Sumber: data sekunder diolah, 2017

Tabel 6 di atas menunjukkan bahwa hasil pengujian multikolinearitas dengan menggunakan nilai tolerance dan VIF memenuhi asumsi bebas multikolinearitas. Hal ini ditunjukkan dari nilai tolerance $>1$ dan nilai VIF $<10$. Dengan demikian, peneliti dapat menyimpulkan bahwa variabel penelitian bebas dari gejala multikolinearitas.

Data pengujian heteroskedastisitas dapat dilihat pada tabel 7 berikut ini.

Tabel 7. Hasil Uji Heteroskedastisitas

\begin{tabular}{|l|l|c|}
\hline \multirow{2}{*}{ Variabel } & \multicolumn{2}{|c|}{ Hasil Uji } \\
\cline { 2 - 3 } & t-hitung & Sig. \\
\hline
\end{tabular}




\begin{tabular}{|l|c|c|}
\hline KCM & 0.203 & 0.839 \\
\hline LTA & -1.521 & 0.129 \\
\hline LEV & 0.107 & 0.915 \\
\hline
\end{tabular}

Sumber: data sekunder diolah, 2017

Tabel $7 \mathrm{di}$ atas menunjukkan bahwa hasil pengujian heteroskedastisitas dengan menggunakan uji glejser memenuhi asumsi bebas heteroskedastisitas. Hal ini ditunjukkan dari nilai signifikansi hasil perhitungan $>0.05$. Dengan demikian, peneliti dapat menyimpulkan bahwa variabel penelitian bebas dari gejala heteroskedastisitas.

Data pengujian autokorelasi dapat dilihat pada tabel 8 berikut ini.

Tabel 8. Hasil Uji Autokorelasi

\begin{tabular}{|l|c|}
\hline & Nilai \\
\hline Durbin-Watson & 1.744 \\
\hline
\end{tabular}

Sumber: data sekunder diolah, 2017

Tabel 8 di atas menunjukkan bahwa hasil pengujian autokorelasi dengan menggunakan durbin watson memenuhi asumsi bebas autokorelasi. Hal ini ditunjukkan dari nilai durbin watson berkisar antara -2 sampai dengan 2. Dengan demikian, peneliti dapat menyimpulkan bahwa variabel penelitian bebas dari gejala autokorelasi.

Data pengujian hipotesis dapat dilihat pada tabel 9 berikut ini.

Tabel 9. Hasil Uji Hipotesis

\begin{tabular}{|l|c|c|c|c|}
\hline \multicolumn{1}{|c|}{ Variabel } & Ekspektasi & Koefisien & t & Sig. \\
\hline (Constant) & & 0.148 & 0.949 & 0.343 \\
\hline KCM & - & -0.409 & -2.886 & 0.004 \\
\hline LTA & + & 0.008 & 2.352 & 0.019 \\
\hline LEV & + & 0.125 & 3.268 & 0.001 \\
\hline Dependen: MAR & \multicolumn{4}{|l}{} \\
$\mathrm{R}^{2}=0.067$ & & \\
F $=9.639$ & & \\
Sig. $=0.000$ &
\end{tabular}

Sumber: data sekunder diolah, 2017

Tabel 9 di atas menunjukkan bahwa variabel kecakapan managerial, ukuran perusahaan dan leverage dapat menjelaskan variabel manipulasi aktivitas riil sebesar $6.7 \%$. Sedangkan 93.2\% dijelaskan oleh faktor-faktor lain di luar model penelitian ini.

Variabel kecakapan managerial memiliki koefisien regresi sebesar -0.409; t hitung sebesar -2.886; dan nilai signifikansi sebesar 0.004 (kurang dari 0.05). Dari hasil tersebut, peneliti dapat menyimpulkan bahwa hipotesis terdukung. Artinya bahwa kecakapan managerial mampu memitigasi manipulasi aktivitas riil.

Variabel kontrol untuk ukuran perusahaan (LTA) memiliki koefisien regresi sebesar 0.008; t hitung sebesar 2.352; dan nilai signifikansi sebesar 0.019 (kurang dari 0.05). Dari hasil tersebut, peneliti dapat menyimpulkan bahwa ukuran perusahaan berpengaruh positif dan signifikan terhadap managemen laba riil. Variabel leverage memiliki koefisien regresi sebesar 
0.125; t hitung sebesar 3.268; dan nilai signifikansi sebesar 0.001 (kurang dari 0.05). Dari hasil tersebut, peneliti dapat menyimpulkan bahwa leverage berpengaruh positif dan signifikan terhadap managemen laba riil.

Hasil penelitian menunjukkan bahwa kecakapan managerial mampu memitigasi adanya manipulasi aktivitas riil. Artinya bahwa semakin tinggi kecakapan managerial, maka semakin rendah tindakan manipulasi aktivitas riil yang dilakukan oleh manager. Hal ini menunjukkan bahwa semakin cakap seorang manager, maka manager akan mampu untuk mendesain proses bisnis perusahaan secara efisien dan membuat keputusan-keputusan yang memberikan nilai tambah bagi perusahaan (Isnugrahadi dan Kusuma, 2009). Manager yang cakap akan mampu mengambil keputusan-keputusan ekonomi yang tepat untuk mencapai tingkat efisiensi yang tinggi dalam mengelola sumber daya perusahaan karena didukung dengan pengalaman, tingkat intelegensia, dan tingkat pendidikan yang tinggi, sehingga manager mampu meraih laba yang optimal.

Manager yang cakap akan berusaha untuk terus meningkatkan kualitas kinerjanya dengan menggunakan sumber daya secara tepat agar dapat memberikan nilai tambah bagi perusahaan daripada manager harus melakukan manipulasi aktivitas riil yang memiliki resiko gagal dalam mempertahankan kepercayaan pemegang saham dan berdampak pada kinerja jangka panjang perusahaan. Manager yang memiliki pengetahuan bisnis yang baik, kemampuan judgment dan estimasi yang akurat, serta ahli dalam bidang tanggung jawabnya akan mengambil keputusan bisnis yang berdampak pada aktivitas perusahaan yang efisien. Dampak dari adanya pengetahuan bisnis yang baik, kemampuan pengambilan keputusan yang efektif dan efisien, serta keahlian yang dimiliki oleh manager yaitu akan memberikan nilai tambah bagi perusahaan untuk mencapai laba yang optimal. Hasil penelitian ini konsisten dengan hasil penelitian yang dilakukan oleh Demerjian dkk. (2012) yang menunjukkan bahwa kecakapan managerial berpengaruh negatif terhadap manipulasi aktivitas riil.

Salah satu contoh dari kecakapan managerial adalah kemampuan manager dalam memprediksi adanya permintaan produk di pasar. Manager yang cakap akan mampu memprediksi adanya permintaan produk dengan akurat dan mampu menggunakan sumber daya yang ada secara efisien untuk menghasilkan output yang maksimal (peningkatan penjualan). Dengan adanya efisiensi sumber daya yang dilakukan oleh manager, maka akan tercipta nilai tambah bagi perusahaan berupa peningkatan penjualan untuk menghasilkan laba yang optimal. Hal ini menunjukkan bahwa manager akan berusaha untuk meningkatkan kualitas kinerjanya dengan memanfaatkan efisiensi sumber daya untuk meningkatkan laba perusahaan sehingga manager yang cakap tidak membutuhkan managemen laba untuk memperbagus laba. 
Ukuran perusahaan sebagai variabel kontrol dalam penelitian ini berpengaruh positif dan signifikan terhadap manipulasi aktivitas riil. Hal ini menunjukkan bahwa semakin besar perusahaan, maka semakin besar pula kesempatan manager untuk melakukan manipulasi laba. Hal ini disebabkan karena perusahaan besar cenderung dituntut untuk memenuhi ekspektasi pemegang saham. Selain itu, pemegang saham lebih banyak menghadapi tekanan untuk mencapai ekspektasi analis (Barton dan Simko, 2002). Hasil penelitian ini konsisten dengan hasil penelitian yang dilakukan oleh Halim dkk. (2005) yang menunjukkan bahwa ukuran perusahaan berpengaruh positif terhadap managemen laba.

Leverage sebagai variabel kontrol dalam penelitian ini berpengaruh positif dan signifikan terhadap manipulasi aktivitas riil. Hal ini menunjukkan bahwa jika perusahaan memiliki leverage yang tinggi untuk mendanai aset atau investasinya, maka manager cenderung melakukan manipulasi aktivitas riil untuk mengatur angka laba yang dihasilkan dengan tujuan untuk menarik minat pemegang saham atau kreditur yang ingin memberikan pinjaman dana atau perpanjangan kontrak. Hasil penelitian ini konsisten dengan hasil penelitian yang dilakukan oleh Isnugrahadi dan Kusuma (2009) yang menunjukkan bahwa leverage berpengaruh positif terhadap managemen laba.

\section{Kesimpulan, Keterbatasan, dan Saran}

\subsection{Kesimpulan}

Penelitian ini bertujuan untuk menguji apakah kecakapan managerial mampu memitigasi tindakan manager melakukan manipulasi aktivitas riil. Penelitian ini dilakukan pada perusahaan manufaktur yang terdaftar di Bursa Efek Indonesia (BEI) dari tahun 2008-2015 dengan mempertimbangkan tahun 2009 dan 2008 untuk menghitung manipulasi aktivitas riil. Sampel penelitian diperoleh melalui teknik purposive sampling dan setelah dikurangi dengan data outliers, maka total sampel berjumlah 407 observasi.

Hasil penelitian ini konsisten dengan penelitian sebelumnya yang menunjukkan bahwa kecakapan managerial mampu memitigasi tindakan manager melakukan manipulasi aktivitas riil. Artinya apabila kecakapan managerial tinggi, maka manipulasi aktivitas riil semakin berkurang. Manager yang cakap akan berusaha untuk meningkatkan kualitas kinerjanya dengan cara mengelola sumber daya yang ada secara efisien, sehingga akan memberikan nilai tambah bagi perusahaan daripada managemen perusahaan harus melakukan manipulasi aktivitas riil yang memiliki risiko kehilangan kepercayaan publik dan mengorbankan kinerja jangka panjang. Dengan demikian, hipotesis secara statistik terdukung. 
Ukuran perusahaan sebagai variabel kontrol dalam penelitian ini berpengaruh positif dan signifikan terhadap manipulasi aktivitas riil. Perusahaan besar cenderung dituntut untuk memenuhi ekspektasi pemegang saham. Selain itu, pemegang saham lebih banyak menghadapi tekanan untuk mencapai ekspektasi analis (Barton dan Simko, 2002). Hasil penelitian ini konsisten dengan hasil penelitian yang dilakukan oleh Halim dkk. (2005) yang menunjukkan bahwa ukuran perusahaan berpengaruh positif terhadap managemen laba.

Leverage sebagai variabel kontrol dalam penelitian ini berpengaruh positif dan signifikan terhadap manipulasi aktivitas riil. Perusahaan yang memiliki leverage tinggi untuk mendanai aset atau investasinya, maka manager cenderung melakukan manipulasi aktivitas riil untuk mengatur angka laba yang dihasilkan dengan tujuan untuk menarik minat pemegang saham atau kreditur yang ingin memberikan pinjaman dana atau perpanjangan kontrak. Hasil penelitian ini konsisten dengan hasil penelitian yang dilakukan oleh Isnugrahadi dan Kusuma (2009) yang menunjukkan bahwa leverage berpengaruh positif terhadap managemen laba.

\subsection{Keterbatasan}

Beberapa keterbatasan dalam penelitian ini yang perlu menjadi bahan perhatian penelitian selanjutnya, yaitu:

1. Penelitian ini hanya mengukur kecakapan managerial pada industri manufaktur. Hal ini disebabkan karena skor kecakapan managerial kemungkinan hanya cocok pada jenis industri manufaktur.

2. Klasifikasi industri manufaktur sebagai dasar pengelompokkan perhitungan skor efisiensinya hanya berdasarkan fact book tanpa melihat kondisi operasi utama perusahaan.

\subsection{Saran}

Saran untuk penelitian selanjutnya adalah sebagai berikut.

1. Penelitian selanjutnya diharapkan dapat menggunakan proksi kecakapan managerial yang digunakan oleh Demerjian dkk. (2012) dan Isnugarahdi dan Kusuma (2009).

2. Penelitian selanjutnya diharapkan dapat menggunakan variabel lain untuk menguji faktorfaktor yang dapat memitigasi manager melakukan manipulasi aktivitas riil seperti kepemilikan managerial, komposisi dewan komisaris dan lain-lain.

\section{Daftar Pustaka}

Aier, J. K., J. Comprix, M. T. Gunlock, and D. Lee. 2005. The Financial Expertiseof CFOs and Accounting Restatements. Accounting Horizons. Vol. 19. No.3: 123-135. 
Barton, J., Simko, P.J., 2002. "The balance sheet as an earnings management constraint", The Accounting review 77 (Supplement), 1-27

bar, M., J. Elliott, and M. Finn. 1999. Market rewards associated with patterns of increasing earnings. Journal of Accounting Research 37 (2): 387-413.

Barto, E., D. Givoly, and C. Hayn. 2002. The rewards to meeting or beating earnings expectations. Journal of Accounting and Economics 33: 173-204.

Bernard, V., J. Thomas, and J. Abarbanell. 1993. How sophisticated is the market in interpreting earnings news? Journal of Applied Corporate Finance 6 (2): 5463.

Bertrand, M. dan A. Schoar, 2003, Managing With Style: The Effect of Managers on Firm Policies, The Quarterly Journal of Economics, Oxford.

Brown, L., and M. Caylor. 2005. A temporal analysis of quarterly earnings thresholds: Propensities and valuation consequences. The Accounting Review 80 (2): 423.440.

Bushman, R. M., and A. J. Smith. 2001. Financial Accounting Information and Corporate Governance. Journal of Accounting and Economics. Vol. 32:237-333.

Cohen, D. A., A. Dey, and T. Z. Lys. 2008. Real and Accrual-Based Earnings Management in the Pre- and Post-Sarbanes-Oxley Periods. The Accounting Review. Vol. 83, No. 3: 757-787.

Cohen, D. A., and P. Zarowin. 2008. Economic Consequences of Real and Accrual-Based Earnings Management Activities. Working Paper. SternSchool of Business New York University.

Chen, Z. a,nd Wakabayashi, M. (1997) Managerial skills in Chinese state-owned corporations, Japanese Journal of Administrative Behavior, 11(1), 35-48.

Dechow, P. M., and I. D. Dichev. 2002. The Quality of Accruals and Earnings:The Role of Accrual Estimation Errors. The Accounting Review. Vol. 77. Supplement: 35-59.

Demerjian, P., B. Lev, and S. E. McVay. 2012. Quantifying Managerial Ability: A New Measure and Validity Tests. Management Science. Vol. 58. No. 7:1229-1248.

Demerjian, P., M. Lewis, and S. McVay. 2012. Managerial Ability And Earnings Management. Working Paper.

Demerjian, P., B. Lev, M. F. Lewiss, and S. E. McVay. 2013. Managerial Ability and Earnings Quality. The Accounting Review. Vol. 88. No. 2 : 463-498.

Financial Accounting Standard Boards. 1978. Statement of Financial Accounting Concepts No. 1. Objectives of Financial Reporting by Business Enterprises.

Francis, J., A. H. Huang, S. Rajgopal, and A. Y. Zang. 2008. CEO Reputation and Earnings Quality. Contemporary Accounting Research. Vol. 25. No. 1: 109-147.

Francis, J. R., and D. Wang. 2008. The Joint Effect of Investor Protection and Big 4 Audits on Eamings Quality around the World. Contemporary AccountingResearch. Vol. 25. No. 1: 157-191.

Gunny, K. 2005. What Are the Consequences of Real Earnings Management? Working Paper.

Gunny, K. 2010. The Relation Between Earnings Management Using Real Activities Manipulation and Future Performance: Evidence from MeetingEarnings Benchmarks. Contemporary Accounting Research. Vol. 27. No. 3:855-888.

Graham, J. R., C. R. Harvey, and S. Rajgopal. 2005. The Economic Implications Of Corporate Financial Reporting. Journal of Accounting and Economics. Vol. 40. No. 1: 3-73. 
Halim, Julia, Carmel M, dan Tobing R.L. 2005. "Pengaruh Manajemen Laba pada Tingkat Pengungkapan Laporan Keuangan pada Perusahaan Manufaktur yang Termasuk pada LQ-45." SNA VIII, Ikatan Akuntan Indonesia, Solo.

Isnugrahadi, I., dan I. W. Kusuma. 2009. Pengaruh Kecakapan Manajerial terhadap Manajemen Laba dengan Kualitas Auditor sebagai VariabelPemoderasi. Simposium Nasional Akuntansi XII Palembang.

Jensen, M. C., and W. Meckling. 1976. Theory of the Firm: Managerial Behavior, Agency Costs and Ownership Structure. Journal of Financial Economics. Vol. 3: 305-360.

Kasznik, R., and M. McNichols. 2002. Does meeting earnings expectations matter? Evidence from analyst forecast revisions and share prices. Journal ofAccounting Research 40 (3): 727-759.

Klein, A. 2002. Economic Determinants of Audit Committee Independence. Accounting Review. Vol. 77. No. 2: 435-453.

Kusuma, H. \& Susanto, E. 2004. Efektivitas Mekanisme Bonding: Kasus PerusahaanPerusahaan yang Dikontrol Komisaris Independen. Jurnal Akuntansi dan Auditing Indonesia, Vol.8, No.1, pp.23-41

Payne, J. and W. Thomas (2010), 'The Torpedo Effect: Myth or Reality?', Journal of Accounting, Auditing and Finance (forthcoming).

Rees, L., and K. Sivaramakrishnan. 2007. The effect of meeting or beating revenue forecasts on the association between quarterly returns and earnings forecast errors. Contemporary Accounting Research 24 (1): 259-290.

Roychowdhury, S. 2006. Earnings Management through Real Activities Manipulation. Journal of Accounting and Economic. Vol. 42: 335-370.

Skinner, D., and R. Sloan. 2002. Earnings surprises, growth expectations, and stock returns or Don't let an earnings torpedo sink your portfolio. Review ofAccounting Studies 7 (2-3): 289-312.

Ujiyantho dan Pramuka. 2007. Mekanisme Corporate Governance, Manajemen Laba dan Kinerja Keuangan. Simposium Nasional Akuntansi X, Unhas Makassar.

Vajriyanti, E., Widanaputra, A.A.G.P., Putri, I.G.A.M.Pengaruh Manajemen Laba Riil pada Nilai Perusahaan dengan Good Corporate Governance sebagai Variabel Pemoderasi. Simposium Nasional Akuntansi XVIII, USU Medan.

Wagner, S., 2008, Managerial Succesion and Organizational Performance,

Munich School of Management.

Watts, R. L., and J. L. Zimmerman. 1986. Positive Accounting Theory. PrenticeHall Inc: New York.

Zang, A. Y. 2012. Evidence on the Trade-Off between Real Activities Manipulation and AccrualBased Earnings Management. The AccountingReview. Vol. 87. No. 2: 675-703. 